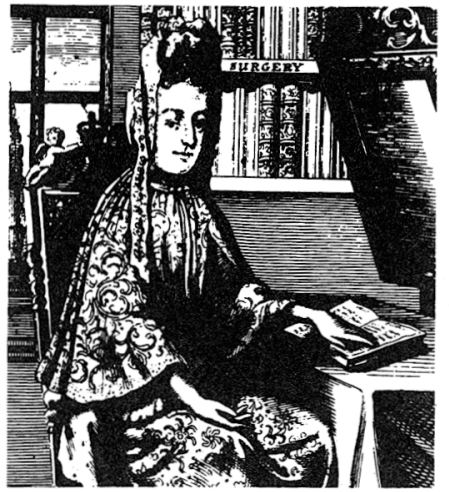

THE CELEBRATED MARY ASTELL

An Early English Feminist

Ruth Perry

Foreword by

Catharine R. Stimpson

"Ruth Perry's new biography of Mary Astell (1666-1731) is an event in the history of women's studies. This is the first modern full-length study of a writer who has with justice been called 'the first feminist'. The discovery of new manuscript material is good news; the generous transcription of Astell's letters and poems is in itself sufficient to make this book indispensable to scholars."-Margaret Anne Doody

Paper \$19.95 576 pages 25 halftones

Library cloth edition $\$ \mathbf{\$ 4 5 . 0 0}$

Women in Culture

and Society series

\section{DECONSTRUCTION IN CONTEXT}

Literature and Philosophy Edited by Mark C. Taylor

"Mark Taylor reconstitutes a set of premises without which no deconstruction could have seen the light of day."

- Jacques Derrida

"The book will be of great value as a set of readings with authoritative explanation for all those interested in the current relations of literature and philosophy. It is the best book of its kind I know."-J. Hillis Miller

Paper \$16.95 464 pages Library cloth edition \$45.00
THE BEST IN CHILDREN'S BOOKS

The University of Chicago

Guide to Children's Literature, 1979-1984

Zena Sutherland

Designed to aid adults

- parents, teachers,

librarians-in selecting from the best of recent children's literature, this guide provides 1,400 reviews of books published between 1979 and 1984. This volume carries on the tradition established by Zena Sutherland's two earlier collections and includes comprehensive indexes by title, by curriculum, by reading level, by subject, and by type of literature.

Cloth $\$ 35.00528$ pages
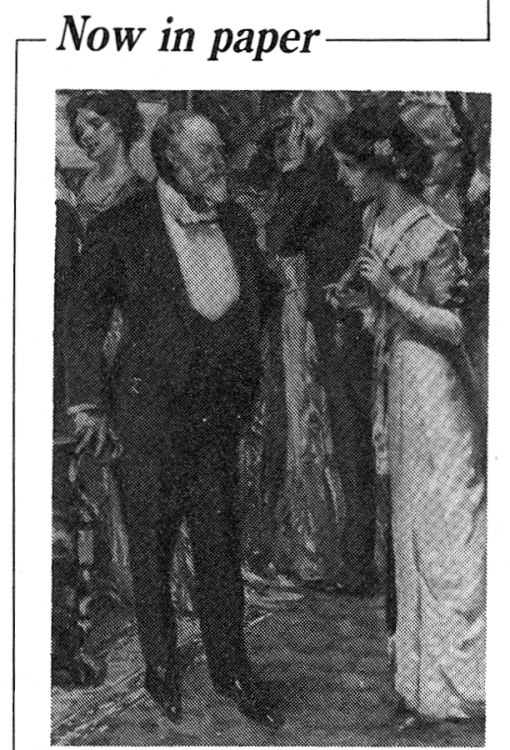

\section{GOSSIP}

Patricia Meyer Spacks

"Gossip offers not only arresting perspectives on both the written and the spoken word but also subtle discussions of particular issues, especially in literature."-Sissela Bok, Boston Globe

$\$ 10.95308$ pages (est.)
Now in paper

\section{ETYMOLOGIES AND GENEALOGIES}

A Literary Anthropology of the French Middle Ages

R. Howard Bloch

"A new synthesis which will enable us to read the Middle Ages in a different light . . . ingenious and compelling."-Times Literary Supplement

$\$ 11.95294$ pages

\section{WITTGENSTEIN}

\section{A. J. Ayer}

A balanced, accessible account of Wittgenstein's life, his work, and his ideas on religion and magic, mathematics and psychology.

$\$ 8.95168$ pages

\section{LOVE KNOWN}

Theology and Experience in George Herbert's Poetry Richard Strier

"The first thorough-going attempt to integrate the aesthetic appreciation of Herbert's poetry with the religious."-John Coolidge

"Absolutely first-rate." - Stanley Fish

$\$ 12.95300$ pages

\section{THE LANGUAGES OF CRITICISM AND THE STRUCTURE OF POETRY}

\section{Ronald S. Crane}

"Nothing I know of matches its systematic placement of the variety of critical possibilities; its statement of critical pluralism is exemplary." -Wayne C. Booth 


\section{Contemporary Griticism/Classical Texts}

\section{THE RHETORIC OF IMITATION \\ Genre and Poetic Memory in Virgil \\ and Other Latin Poets}

By GIAN BIAGIO CONTE. Translated from the Italian. Edited and with an Introduction by CHARLES SEGAL. This collection of essays, all of which were previously published in Italian, introduces to English-language readers a major innovative European classicist whose work combines the sophisticated methodology of semiotic theory with rigorous linguistic study. Cornell Studies in Classical Philology. $\$ 22.50$

\section{INTERPRETING GREEK TRAGEDY}

Myth, Poetry, Text

By CHARLES SEGAL. "Segal is at the forefront of the integration of contemporary literary theory and classical philology. He combines a rigorous and scholarly approach to the texts with the methodological concerns of contemporary literary critics, field of classical studies into the intellectual universe of the twentieth century with admirable tact and illuminating insight."-Page duBois, University of California, San Diego. $\$ 12.95$ paper; $\$ 39.50$ cloth

\section{ARTIFICES OF ETERNITY}

Horace's Fourth Book of Odes

By MICHAEL C. J. PUTNAM. "This work is one of the most original and stimulating discussions of Latin literature in many years-an elegant, highly nuanced, and balanced study, setting forth with verve and authority Horace's art."-Charles Witke, Cornell Studies in Classical Philology/Townsend Lectures series.

\section{Announcing the first volume in a new series MASTERS OF LATIN LITERATURE THREE TRAGEDIES BY SENECA \\ "Trojan Women," "Medea," and "Phaedra" Translated and with Introductions by FREDERICK AHL. "Ahl's translations reveal a genuine, imaginative response to the playwright. ... I do not think a translator can come closer to being 'Senecan.' "-Eleanor Winsor Leach, Indiana University.

New in paperback...

\section{ROMAN COMEDY}

By DAVID KONSTAN. "This book will interest the literary-minded with a particular interest in the theatre; they will find much that is illuminating."-The Classical Outlook.

\section{VISUAL NARRATTVES}

Storytelling in Etruscan and Roman Art

By RICHARD BRILLIANT. "Exploring the interrelationship of visual and written narrative, Brilliant makes fascinating parallels between the ancient artist and classical author."-Art Documentation. 72 b\&w illustrations. 